\title{
The Biological Activity and the Binding Affinity of Modified Insulins Determined on Isolated Rat Fat Cells
}

\author{
J. Gliemann and S. Gammeltoft* \\ Received: August 16, 1973, and in revised form: November 12, 1973
}

\begin{abstract}
Summary. A number of modified insulins were assayed for biological activity (increase in synthesis of lipids from glucose) and binding affinity (inhibition of receptorbinding of ${ }^{125}$ I-insulin) on rat fat cells and the following was found: -1 . The modified insulins tested showed the same maximal effect as native insulin. Decrease in biological activity induced by modifications was interpreted as decrease in potency. - 2. Removal of 2 amino acids from the amino-terminal end of the $B$ chain caused little or no decrease in potency. Removal of 5 amino acids from the carboxy-terminal end of the $\mathbf{B}$ chain caused a decrease in potency to about $17 \%$ of that of insulin. Removal of one amino acid (glycine) from the amino-terminal end of the A chain caused a decrease in potency to about $1 \%$. -3 . Substitutions with acetyl or succinyl residues at position A1 had a greater effect on the potency than substitution at position $\mathrm{B} 1$ or $\mathrm{B} 29$. - 4. Cross linkage between posi-
\end{abstract}

tions A1 and B29 caused decreases in potency on fat cells to between 2 and $10 \%$. Cross linkage between positions $\mathrm{A} 1$ and $\mathrm{B} 1$ almost abolished biological activity. 5. 9 of the modified insulins were tested for ability to inhibit binding of ${ }^{\mathbf{1 2 5}} \mathrm{I}$-insulin to fat cell receptor sites. The decrease in receptor binding affinity induced by chemical modifications was, in all cases, in agreement with the decrease in biological potency. -6 . It is concluded that the binding affinity of insulin to the receptor, and therefore the potency, is dependent on (1.) a largely unchanged tertiary structure of the insulin molecule and (2.) free access to the region of the amino-terminal end of the $A$ chain.

Key words: Modified insulins, isolated fat cells, insulin structure-function relationship, insulin receptor, ${ }^{125}$ I-insulin binding.
One approach to the study of the molecular basis of insulin action has been the investigation of the relationship between structure and activity of chemically or enzymatically modified insulins. During the past 5 years several modifications of the insulin molecule have been carried out and this report describes results on modified insulins obtained predominantly from Deutsches Wollforschungsinstitut, Aachen. The methods of preparation and the chemical characteristics have been reported previously by the Aachen group, in some cases together with preliminary data on the biological activity in vitro, as determined by the isolated fat cell assay in our laboratory [1-14]. A summary of some of these data has recently appeared in a review by Blundell et al. [15].

A recent development in the study of the mechanism of insulin action has been the demonstration of specific binding of ${ }^{125} \mathrm{I}$-insulin to receptor sites in various cell types [16-20] and studies in our laboratory [20] have shown that isolated fat cells possess receptors with a dissociation constant of about $3 \mathrm{nM}$.

The present report describes the biological activity (intrinsic activity, i.e. the maximal effect produced by a modified insulin compared with that produced by insulin, and potency, i.e. the concentration required for a modified insulin to produce half of the maximal effect as compared to the concentration required for insulin) and the receptor binding affinity, on isolated rat fat cells, of a number of modified insulins. The aim

* With the technical assistance of G. Hjeresen and T. Johansen. of the work has been: 1. To search for parts of the insulin molecule responsible for the biological effect by determining the necessary requirements for biological activity. 2 . To evaluate the biological significance of the receptor sites by comparing changes in potency with changes in binding affinity.

\section{Material and Methods}

\section{Chemicals}

$\mathrm{U}-{ }^{14} \mathrm{C}$-glucose and $2{ }^{3} \mathrm{H}$-glucose were obtained from the Radiochemical Centre, Amersham. 125I-insulin (0.1-0.2 mole I/mole insulin) was prepared by Drs. K.H. Jørgensen and U.D. Larsen, NOVO Research Institute, at a specific activity of $20-30 \mathrm{mCi} / \mathrm{mg}$. Native porcine insulin (10 times crystallized, $25 \mathrm{U} / \mathrm{mg}$ ) was a gift from NOVO. The standard insulin was dissolved in albumin solution (1\% in water) and kept frozen in small aliquots. Crude collagenase and bovine serum albumin were obtained from Sigma.

The modified insulins were obtained from Deutsches Wollforschungsinstitut, Aachen with the exception of des-Ala ${ }^{\mathrm{B} 30}$-des-Asn ${ }^{\mathrm{A} 21}$ insulin, which was kindly provided by Dr. E. Arquilla. Table 1 gives the shorthand nomenclature used in the text below and Fig. 1 illustrates the tertiary structure of the insulin monomer.

\section{The Isolated F'at Cell Assay}

Isolated fat cells were prepared from epididymal and perirenal fat of $100-150 \mathrm{~g} a d l i b$ fed, male Wistar rats. The method of preparation was as described by 
Gliemann [21] using collagenase $0.5 \mathrm{mg} / \mathrm{ml}$. The incubations were carried out with low concentrations of cells $(2-5 \mu l$ cells $/ m l$ suspension) in order to ensure negligible degradation of insulin [20]. The early experiments were carried out with $\mathrm{U}^{11} \mathrm{C}$-glucose and ${ }^{14} \mathrm{CO}_{2}$ was collected and counted as described [21]. Later experiments were carried out using $2{ }^{3} \mathrm{H}$-glucose and the total lipids were extracted by addition of scintillation fluid directly to the incubation vial and counted as described by Moody et al. [22]. Some modified insulins were tested in both systems and the results were identical. mean value with $95 \%$ confidence limits. In other cases, the modified insulins were tested in a maximally stimulating concentration and in two concentrations which gave responses corresponding to the steep slope of the insulin standard curve, cf. Fig. 2B. These assays were carried out at least twice on samples which were dissolved and diluted separately and the results are given as the mean value. The difference between such duplicate estimates did not exceed $20 \%$. All potency estimates are expressed on a molar basis.

In some cases a modified insulin preparation had no effect on fat cells, even in a concentration of $10^{-8} \mathrm{M}$,

Table 1. Structure of some modified insulins, nomenclature and abbreviations. Primary structure of bovine insulin is shown on top

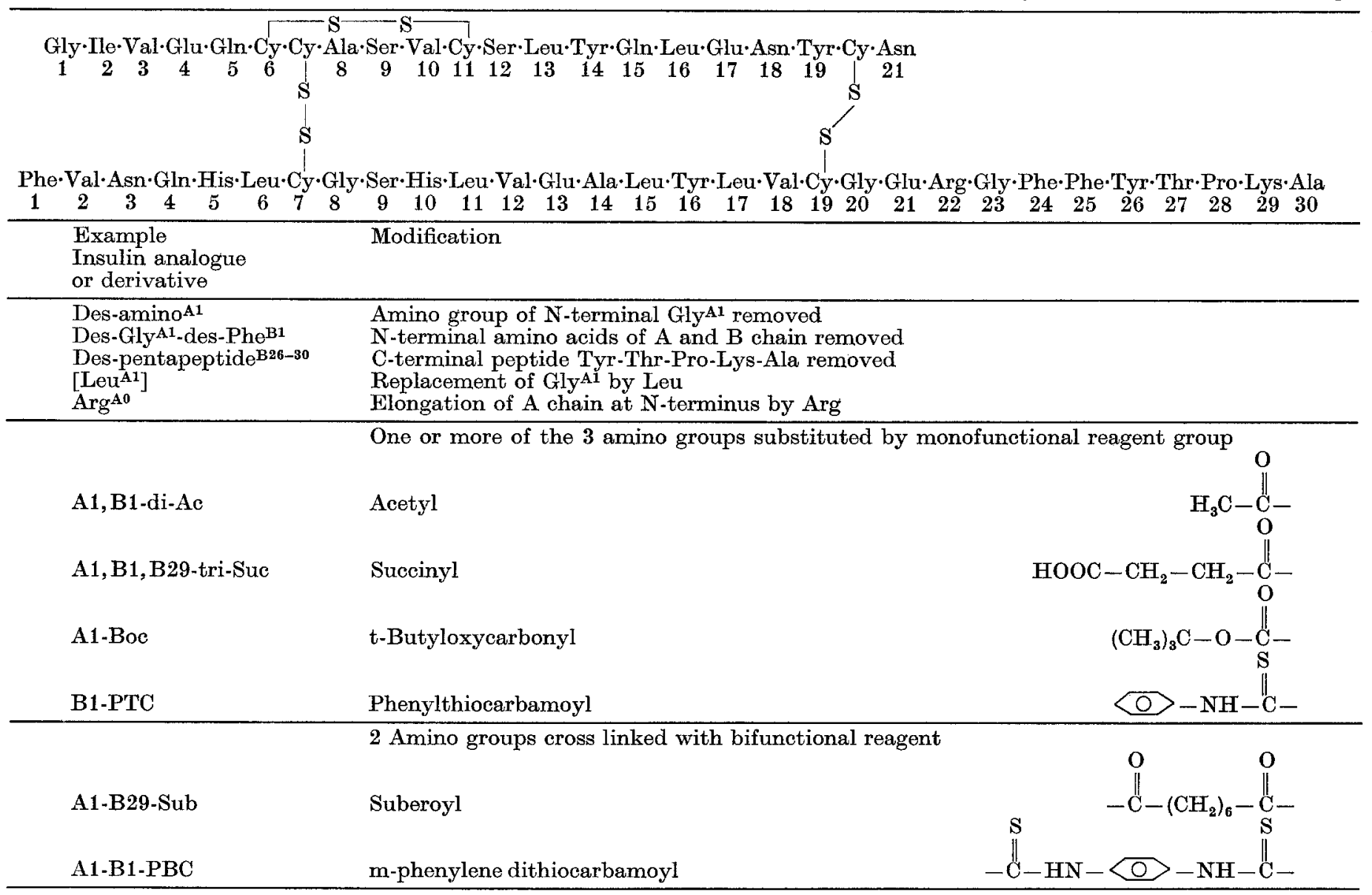

The biological activity (conversion of $\mathrm{U}^{14} \mathrm{C}-\mathrm{glucose}$ to ${ }^{14} \mathrm{CO}_{2}$ or incorporation of $2{ }^{3} \mathrm{H}$-glucose into lipids) was estimated in two different ways: In some cases, complete dose-response curves were carried out on both a modified insulin and the standard insulin, of. Fig. 2A. The concentration of the modified insulin (in mole/l) required to cause half of the maximal effect was determined on 4 dose-response curves, each of which was determined with 4 replicate values for each hormone concentration. The potency was estimated for each pair of curves and the results are given as the and the results are accordingly given in the tables as $<0.2 \%$. None of these preparations assayed in higher concentrations because it was difficult to exclude a minor contamination with native insulin or insulin analogue of high potency.

\section{Estimation of Binding Affinity}

Fat cells $(10 \mu \mathrm{l} / \mathrm{ml})$ were incubated, as previously described [20], with ${ }^{125}$ I-insulin in a concentration of $7 \times 10^{-10} \mathrm{M}$, either alone or with native insulin in concentrations of $2.3 \times 10^{-10} \mathrm{M}-7 \times 10^{-7} \mathrm{M}$ or with 
modified insulin in appropriate concentrations (cf. Fig. 3). The cells were separated from the buffer as previously described [23] and counted, together with aliquots of the medium, in a well-type $\gamma$-counter. The distribution coefficient $\mathrm{Q}\left[={ }^{125} \mathrm{I}\right.$-activity per 1 cells $/$ ${ }^{125}$ I-activity per 1 medium] was determined with 8 re-

\section{Results}

\section{Biological Activities}

Insulins modified by removal or replacement of amino acids. Several of the modified insulins were prepared by recombination of synthetic or semisynthetic chain

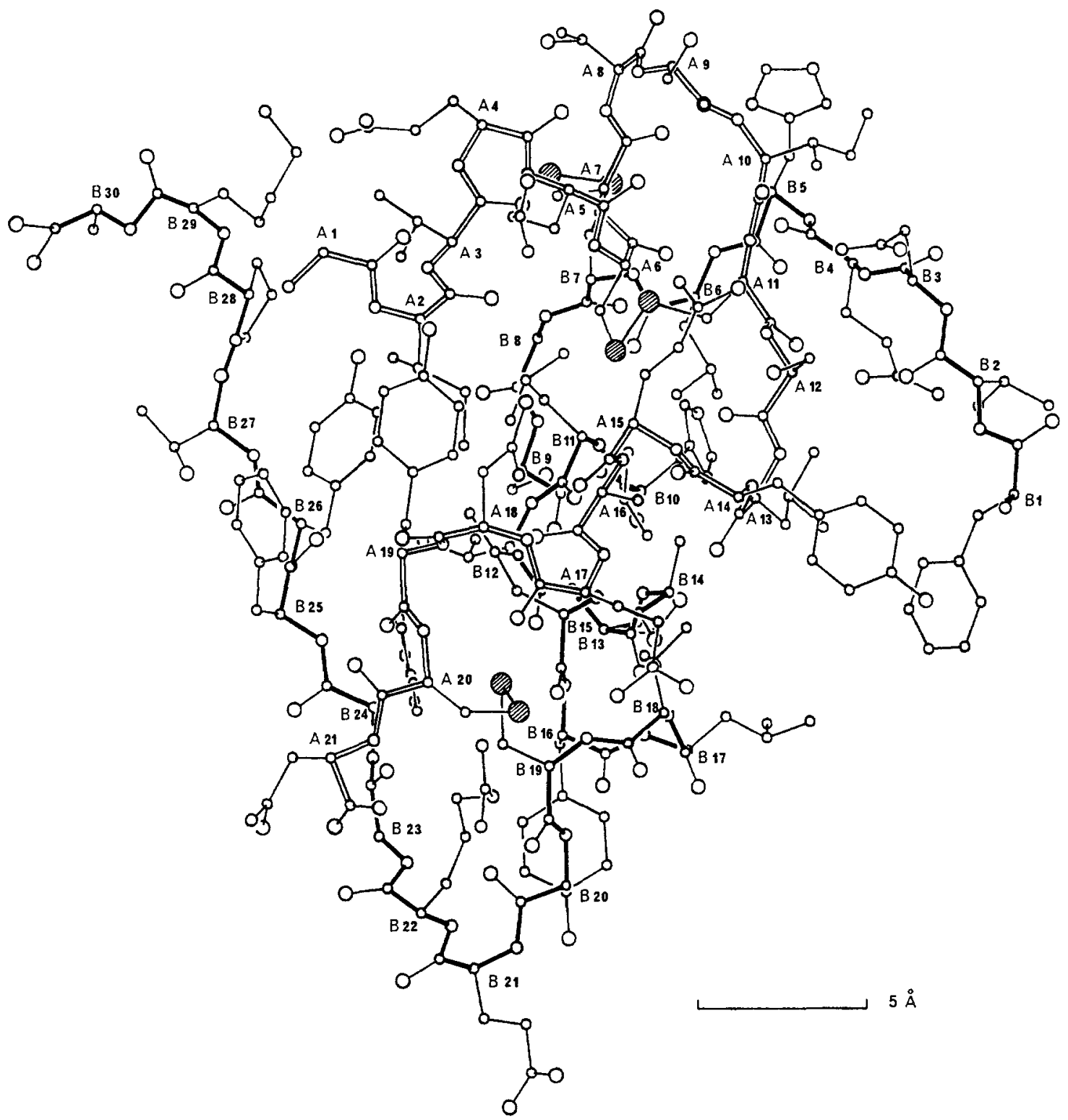

Fig. 1. The atomic positions in the insulin molecule in a projection perpendicular to the c-axis. From Blundell et al. Nature $231,506-511$ (1971). With the permission of Drs. T. Blundell and G. Dodson

plicates at each concentration of native or modified insulin; the inhibition constant $\left(K_{i}\right)$ for the modified insulin was calculated with the non-linear support plane confidence limits of the $95 \%$ confidence region, as described [20]. analogues with natural chains, followed by isolation from the reaction mixture by gel filtration and ion exchange chromatography. It was therefore essential to control that insulin recombined from natural $A$ and $B$ chains and isolated by the same procedure was fully 


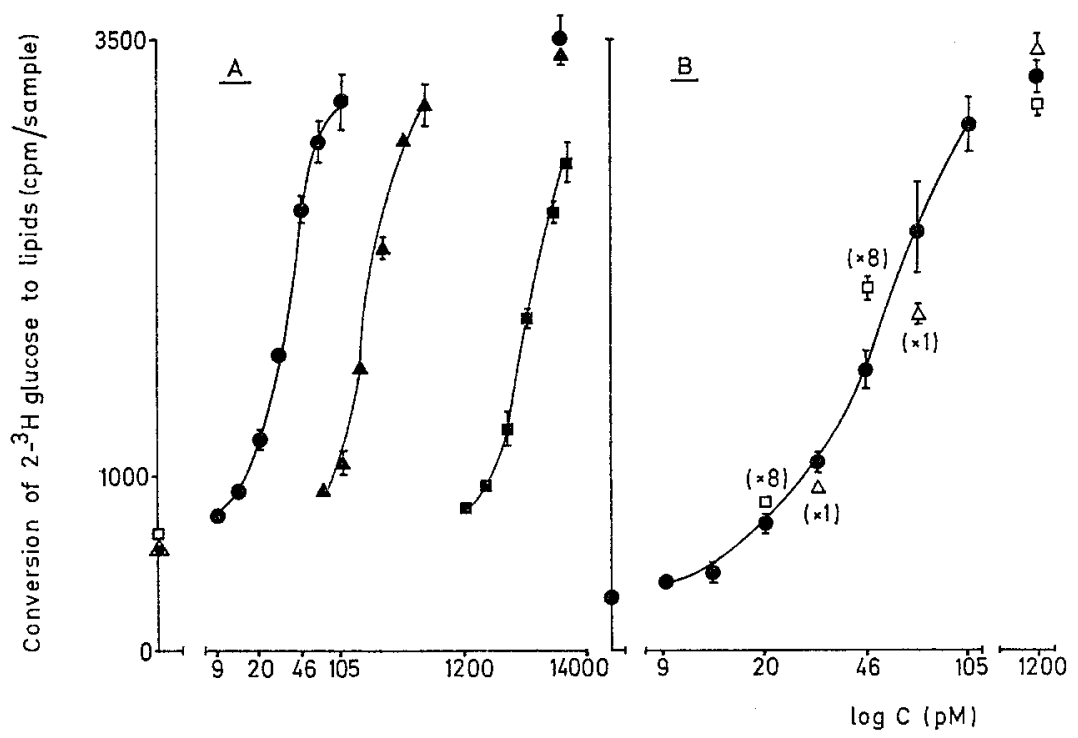

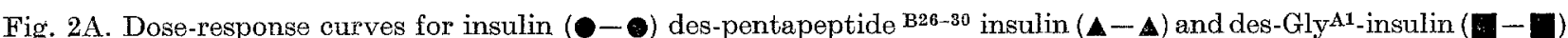
Each point represents the mean of 4 replicates \pm S.D. The potency of the modified insulins was estimated as the ratio: Concentration of insulin (molo/l) required to cause half-maximal effect $\times 100 /$ concentration of modified insulin required to cause half-maximal effect. The figures which appear in the tables represent the mean of 4 such estimates with the $95 \%$ confidence limits

Fig. 2B. Dose-response curve for insulin - and "two-point" assays of des-amino ${ }^{\mathrm{B} 1}$-insulin $(\Delta)$ and A1, B1-di-PTCinsulin ( $\square$ ). The modified insulins were incubated in the concentrations indicated on the abscissa times the multiplication factor shown in brackets. The potency of the modified insulins was estimated as the mean value of the two readings on the insulin standard curve. The figures which appear in the tables represent the mean of two such estimates

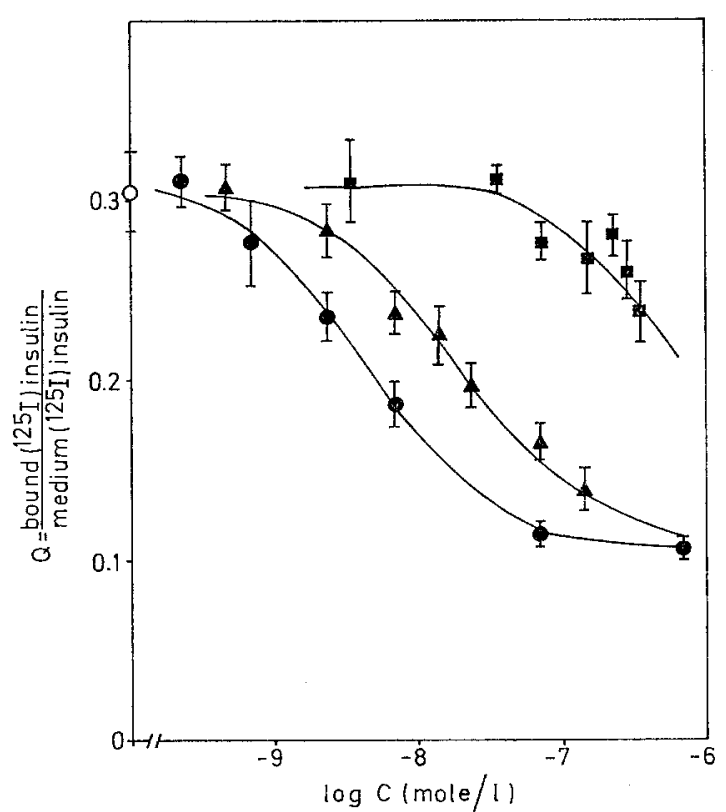

Fig. 3. Inhibition of receptor-binding of $7 \times 10^{-10} \mathrm{M}{ }^{125} \mathrm{I}$ insulin (o) by native insulin (-0) A1 monoacetyl insulin $(\mathbf{A}-\mathbf{A})$ and des GlyA1 insulin (- The fat cells were incubated for $45 \mathrm{~min}$ at $37^{\circ} \mathrm{C}$ with ${ }^{125} \mathrm{~T}$-insulin $7 \times 10^{-10} \mathrm{M}$ and native or modified insulin as indicated. For experimental details and method of calculation, see method section potent, and this was found to be the case in repeated experiments not reported here.

All the investigated insulin analogues which showed activity were tested in concentrations of less than $10^{-8} \mathrm{M}$, among which four examples (despentapeptide B26-30 insulin, des-Gly A1 $^{\text {insulin, des-amino }}{ }^{\text {B1 }}$ insulin and A1, B1,-di-phenylthiocarbamoyl insulin), are shown in Fig. 2A and B, exerted the same maximal effect on glucose metabolism as native insulin. Fig. $2 \mathrm{~A}$ shows that the dose-response curves for despentapeptide ${ }^{\mathrm{B26-30}}$ and des-Gly ${ }^{\mathrm{A} 1}$ insulin were parallel to that of insulin, a phenomenon which was also shared by all other active modified insulins tested. Furthermore, in experiments not shown here, incubations were carried out with native insulin plus a modified insulin with a potency of $12 \%$ of that of insulin (A1-B29 dodecoyl insulin, of. Table 5), both present in submaximally stimulating concentrations. The effect of the modified and the native insulin together was equal to the sum of the effects in parallel, separate incubations (additive effect). The lower biological activity of this analogue, compared to that of insulin, could therefore be explained as a decrease in potency. Finally, none of the modified insulins which were inactive in a concentration of $10^{-8} \mathrm{M}$, i.e. with activities of less than $0.2 \%$ of that of insulin, inhibited the action of insulin $(5 \times$ $10^{-11} \mathrm{M}$ ) when present in a concentration of $10^{-8} \mathrm{M}$.

Table 2 summarizes the results of removing or replacing some amino acids. Des-Ala $\mathrm{B}^{\mathrm{B} 30}$ insulin is fully biologically active as shown before [24]. Removal of 
5 amino acids from the carboxy-terminal end of the B chain still leaves about $17 \%$ of the potency of native insulin, whereas desoctapeptide ${ }^{\mathrm{B} 23-30}$ insulin has a potency of less than $0.2 \%$. Bromer and Chance [25] reported that desoctapeptide insulin was less than 1\% active, whereas Freychet, Roth and Neville [26] found it about $1.5 \%$ active on fat cells. Katsoyannis et al. [27] found bovine destripeptide ${ }^{\mathrm{B} 28-30}$ insulin fully active in the mouse convulsion assay. It also appears from Table 2 that removal of the amino group from $\mathrm{Phe}^{\mathrm{B1}}$ as well as complete removal of the $\mathrm{Phe}^{\mathrm{B1}}$ or $\mathrm{Phe}^{\mathrm{B} 1}$ plus $\mathrm{Val}^{\mathrm{B} 2}$ has little effect on the potency. Weitzel et al. [28]

Table 2. Effect of removal or replacement of some amino acids

\begin{tabular}{|c|c|c|}
\hline Modified insulin & Reference & $\begin{array}{l}\text { Potency, } \% \text { of in- } \\
\text { sulin }(95 \% \text { confi- } \\
\text { dence limits or } \\
\text { mean of } 2 \text { assays, } \\
\text { cf. Fig. } 2 \mathrm{~A} \text { and } \mathrm{B})\end{array}$ \\
\hline Des-Ala ${ }^{\mathrm{B30}}$ & {$[32]$} & $91-105$ \\
\hline Des-amino $^{\mathrm{B} 1}$ & {$[13]$} & 75 \\
\hline Des-Phe $\mathrm{e}^{\mathrm{B} 1}$ & {$[2]$} & $78-102$ \\
\hline Des-Phe ${ }^{\mathrm{B} 1}$-des-Val ${ }^{\mathrm{B} 2}$ & $\mathrm{c}$ & 75 \\
\hline Des-pentapeptide B26-30 & {$[12]^{\mathrm{d}}$} & $15-18$ \\
\hline Des octapeptide $\mathbf{B 2 3 - 3 0}$ & {$[33]$} & $<0.2$ \\
\hline $\operatorname{Des}_{-a m i n o}{ }^{A 1}$ & {$[8]$} & 15 \\
\hline Des-GlyA1 & {$[8]^{a}$} & $0.7-1.2$ \\
\hline Des-GlyA1 & {$[1 \overrightarrow{5}]^{\mathrm{b}}$} & $0.4-0.6$ \\
\hline Des-Gly'A1-des-Phe ${ }^{\mathrm{B} 1}$ & {$[1,8]$} & 2 \\
\hline \multirow{2}{*}{\multicolumn{3}{|c|}{$\begin{array}{l}\text { Des-Gly }{ }^{A 1} \text {-des Ile }{ }^{A^{2}} \text {-des- } \\
\text { Phe }{ }^{1} 1 \text {-des-Yaj }{ }^{B}{ }^{2}\end{array}$}} \\
\hline & [8] & $<0.2$ \\
\hline$[\mathrm{Leu} A 1]$ & [13] & 16 \\
\hline$[$ GluA1] & [13] & 8.9 \\
\hline$[\mathrm{Lys} A 1]$ & {$[13]$} & 3.6 \\
\hline$\left[\mathrm{Pro}^{\mathrm{A1}}\right]$ & [13] & 2.1 \\
\hline$\left[\mathrm{Val}{ }^{\mathrm{A} 1}\right]$ & [13] & $1.9-2.2$ \\
\hline Des-Ala ${ }^{\mathrm{B} 30}$-des-Asn ${ }^{\mathrm{A} 21}$ & {$[29] \mathrm{e}$} & $2.5-3.3$ \\
\hline
\end{tabular}

a Via chain combination with semisynthetic des-GlyA-chain.

b Via chain combination with synthetic des-Gly-Achain.

c Prepared by D. Brandenburg.

d Prepared by H.G. Gattner.

e Prepared by E. Arquilla.

For experimental details and methods of calculation, see method section and text to Fig. 2.

have prepared a synthetic B chain analogue where the $\mathrm{Gln}^{\mathrm{B}}{ }^{4}$, Ser ${ }^{\mathrm{B} 9}$, and $\mathrm{Thr}^{\mathrm{B} 27}$ were replaced with alanine and where the following amino acids were removed: $\mathrm{Phe}^{\mathrm{B} 1}, \mathrm{Val}^{\mathrm{B} 2}, \mathrm{Asn}^{\mathrm{B} 3}$ and Ala ${ }^{\mathrm{B} 30}, \mathrm{Lys}^{\mathrm{B} 29}, \mathrm{Pro}^{\mathrm{B} 28}$. This chain was combined with natural A chain and the unfractionated combination product appeared fully active in the mouse convulsion assay when compared with the combination product of the native insulin chains. However, removal of the amino acid in position B4 from this analogue caused a decrease in activity to less than $10 \%$.

Replacement of the GlyAl by an acetyl residue (desamino ${ }^{A 1}$ ) reduced the potency to $15 \%$ of that of insulin. Replacement of glycine with leucine had a similar effect, whereas the analogue in which glycine is replaced by valine or proline retained only about $2 \%$ of the potency of insulin. Removal of the Gly ${ }^{\mathrm{A}}$ caused a decrease in potency to about $1 \%$ of that of insulin. Removal of the two N-terminal amino acids from both the A chain and the B chain had a similar effect. Removal of the Ala ${ }^{B 30}$ plus Asn ${ }^{A 21}$ caused a decrease in potency to about $3 \%$ (Table 2). Weitzel and coworkers [29-31] have previously reported very low biological activity of unfractionated combination products of natural $B$ chain and A chain analogues in which Gly ${ }^{{ }^{1}}$ was either lacking or replaced with alanine. Slobin and Carpenter [32] and Freychet, Roth and Neville [26] have found that des-Ala ${ }^{B 30}$-des-Asn-A ${ }^{21}$ exhibits a potency in vivo and on isolated fat cells, respectively, which is only a few per cent of that of insulin.

In some experiments the ${ }^{3} \mathrm{H}$-lipids were saponified and it was found that concentrations of insulin, desamino ${ }^{\mathrm{A} 1}$ insulin and des-glycine $\mathrm{A}^{\mathrm{A}}$ insulin, with the same submaximal effect on the incorporation of $2{ }^{3} \mathrm{H}$-glucose into total lipids, also exhibited identical effects on the incorporation into the fatty acids and the glyceride moieties of the triglycerides (data not shown).

Table 3. Effects of elongation of the chains

\begin{tabular}{lll}
\hline Modified insulin & Reference & $\begin{array}{l}\text { Potency, \% of } \\
\text { insulin }\end{array}$ \\
\hline ArgA0 & {$[5]$} & $40-49$ \\
Lys A ${ }^{-1}-$ ArgA0 $^{\text {A0 }}$ & {$[7]$} & $\mathbf{1 7}-21$ \\
Glyb $^{\mathrm{B} 0}$ & {$[13]$} & 49 \\
Leu $^{\mathrm{B} 0}$ & {$[13]$} & 68 \\
Lys & {$[13]$} & 43 \\
\hline
\end{tabular}

These effects of removal or replacement of amino acids (Table 2) agree fairly well with the changes in circular dichroism spectra where the similarity to insulin, as it appears from the ratio $\theta 208 / \theta 222$, follows the order: Ins $\sim$ des-Ala ${ }^{\mathrm{B} 30} \sim$ des-Phe ${ }^{\mathrm{B} 1}>\mathrm{des}^{\mathrm{B} 26-30} \sim$ des-Gly ${ }^{\mathrm{A}^{1}} \sim\left[\mathrm{Leu}^{\mathrm{A} 1}\right]>\left[\mathrm{Val}^{\mathrm{A} 1}\right]>\operatorname{des}^{\mathrm{B}^{23-30}}([15]$, Wollmer, personal communication).

Chain elongation. Table 3 shows that addition of arginine to the $\mathrm{N}$-terminal end of the $\mathrm{A}$ chain reduced the potency to about $45 \%$ and addition of both arginine and lysine ( $\mathrm{Lys}^{\mathrm{A}-1}{ }_{-}$ArgA0) caused a decline in the potency to $20 \%$. The circular dichroism spectra of

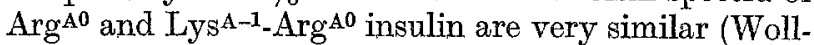
mer, personal communication). Arginine and lysine are the first two amino acids of the C-peptide of proinsulin, which in its single chain form has a potency on fat cells of about $3 \%$ of that of insulin [33]. Addition of leucine, glycine or lysine to the $\mathrm{N}$-terminal end of the B chain has less effect on the potency (Table 3).

Various substitutions. Table 4 summarizes the results. Substitution with acetyl residues (N-acetylation) in the B1 or B29 position had little effect whereas substitution at the A1 position caused a decrease in potency to between one third and half of that of insulin. Similarly, the circular dichroism spectrum for B29-Ac-insulin has been found almost identical with that of insulin, whereas A1-Ac-insulin is rather different 
[10]. The potency of A1,B29-di-Gly-insulin is similar to that of A1,B29-di-Ac-insulin. Substitution with succinyl residues produces a similar 'pattern' in potency as substitution with acetyl residues, but the effect of the larger succinyl residue at the A1 position. is more pronounced. Lindsay and Shall [34] found both di- and triacetylated insulins fully potent in the mouse convulsion assay, whereas Massaglia et al. [35] found reduced activities in the rat epididymal fat pad assay. The acetylated derivatives described here have also been tested for the ability to decrease blood sugar in rats and they could not be distinguished from insulin [10].

It further appears from Table 4 that substitution at B1 or B29 with phenylthiocarbamoyl (PTC) and butyloxycarbonyl (Boc) derivatives caused relatively little decrease in potency, whereas substitution at A1 caused a marked decrease. Substitution at the A1 and B29 positions with tryptophyl (Trp) residues had a similar effect as substitution with acetyl or glycyl residues, whereas substitution with A1,B29-di (Boc-Trp) caused a pronounced decrease in the potency. Arquilla, Bromer and Mercola [36] have previously observed that substitution at position B1 with fluorescein isothiocyanate had a moderate effect on the activity in vivo, whereas substitution at both B1 and A1 had a more pronounced effect.

Finally it is seen that replacement of $\mathrm{Phe}^{\mathrm{BI}}$ with p-iodophenylalanine caused only a moderate decline in potency. This chemically well defined monoiodoinsulin might be suitable for studies on insulin-receptor binding when ${ }^{125} \mathrm{I}$ is used in the synthesis.

Intramolecular cross linkages. Table 5 summarizes the results of the potencies of insulin intramolecularly cross linked with a dicarboxylic acid between A1 and $\mathrm{B} 29$ and between $\mathrm{A} 1$ and $\mathrm{B} 1$. The distance between the $\mathrm{A} 1$ and B29 amino groups of crystalline insulin is $8-10$ $\AA$ [37], which is about the same as the length of the suberic acid chain. The circular dichroism spectrum of the analogue cross linked with suberic acid is virtually identical with A1, B29 diacetyl insulin [12]. The circular dichroism spectrum of diaminosuberoyl insulin resembles even more that of insulin and it also crystallizes as insulin (Brandenburg, personal communication). However, the potency on fat cells of these analogues is only about $5 \%$ of that of insulin. This is in contrast to results obtained on rats in vivo (fall in blood sugar) where the suberoyl and azelaoyl insulins appear to be fully potent [12]. It appears from Table 5 that the potency tended to be higher for the modified insulins with long chain cross linkages. Lindsay recently prepared A1-B29 succinyl insulin [38] and found it $60 \%$ active in vivo (blood sugar depressing effect in rabbits).

Cross linkage between $\mathrm{A} 1$ and $\mathrm{B} 1$, which in the crystal are about $20 \AA$ apart, causes a marked decrease in the potency on isolated fat cells which is in agreement with results obtained in vivo and with the marked changes in the circular dichroism spectrum of m-phenylene dithiocarbamoyl insulin [12]. However, the spectral changes are only moderate for A1-B1 undecoyl and A1-B1 dodecoyl insulin [12].

Table 4. Effects of various substitutions of the insulin molecule

\begin{tabular}{|c|c|c|}
\hline Modified insulin & Reference & $\begin{array}{l}\text { Potency, \% of } \\
\text { insulin }\end{array}$ \\
\hline $\mathrm{B} 1-\mathrm{Ac}$ & $\mathrm{c}$ & 75 \\
\hline B29-Ac & {$[10]$} & 75 \\
\hline $\mathrm{B} 1, \mathrm{~B} 29-\mathrm{di}-\mathrm{Ac}$ & $\mathrm{c}$ & 85 \\
\hline $\mathrm{A} 1-\mathrm{Ac}$ & {$[10]$} & $35-40$ \\
\hline $\mathrm{A} 1, \mathrm{~B} 1-\mathrm{di}-\mathrm{Ac}$ & $\mathrm{c}$ & 32 \\
\hline A1, B29-di-Ac & {$[10]$} & $26-32$ \\
\hline $\mathrm{A} 1, \mathrm{~B} 1, \mathrm{~B} 29$-tri Ac & {$[10]$} & $20-29$ \\
\hline A1, B29-di-Gly & a & 28 \\
\hline B1-Suc & c & 81 \\
\hline B29-Suc & c & 75 \\
\hline B1,B29-di-Suc & $\mathrm{c}$ & 47 \\
\hline A1-Suc & c & $13-15$ \\
\hline A1,B1-di-Suc & c & 14 \\
\hline A1, B1, B29-tri-Suc & c & $6-8$ \\
\hline B1-PTC & {$[2]$} & 71 \\
\hline $\mathrm{A} 1, \mathrm{~B} 1-\mathrm{PTC}$ & {$[2]$} & 16 \\
\hline A1-Boc & {$[13]^{\mathrm{a}}$} & $21-29$ \\
\hline A1-Boc & {$[13]^{\mathrm{b}}$} & $21-30$ \\
\hline B29-Boc & {$[13]$} & $44-55$ \\
\hline A1,B29-di $\operatorname{Trp}$ & $\mathrm{d}$ & $33-41$ \\
\hline A1,B29-di (Boc-Trp) & d & $6-8$ \\
\hline [p-iodophenylalanine $\left.{ }^{B 1}\right]$ & {$[6]$} & $62-73$ \\
\hline
\end{tabular}

a Via substitution

b Via chain combination

c H. G. Gattner, unpublished

d D. Brandenburg, unpublished.

Table 5. Effect of intramolecular cross linkages

\begin{tabular}{|c|c|c|c|}
\hline $\begin{array}{l}\text { No. of } \\
\text { carbons }\end{array}$ & $\begin{array}{l}\text { Modified insulin } \\
\text { (A1-B29 cross linkage) }\end{array}$ & Reference & $\begin{array}{l}\text { Potency, \% } \\
\text { of insulin }\end{array}$ \\
\hline $\begin{array}{l}\mathrm{C}_{2} \\
\mathrm{C}_{4} \\
\mathrm{C}_{5} \\
\mathrm{C}_{6} \\
\mathrm{C}_{7} \\
\mathrm{C}_{8} \\
\mathrm{C}_{8} \\
\mathrm{C}_{9} \\
\mathrm{C}_{10} \\
\mathrm{C}_{11} \\
\mathrm{C}_{12} \\
\mathrm{C}_{13}\end{array}$ & $\begin{array}{l}\text { Oxaloyl } \\
\text { Succinyl } \\
\text { Glutaryl } \\
\text { Adipoyl } \\
\text { Pimeloyl } \\
\text { Suberoyl } \\
\text { Des-Phe }{ }^{\mathrm{Bl}} \text { suberoyl } \\
\text { Azelaoyl } \\
\text { Sebacoyl } \\
\text { Undecoyl } \\
\text { Dodecoyl } \\
\text { Tridecoyl } \\
\text { Cystinyl } \\
\text { Diaminosuberoyl } \\
\text { m-phenylene dithio- } \\
\text { carbamoyl-(B1-PTC) }\end{array}$ & $\begin{array}{l}{[12]} \\
{[12]} \\
{[12]} \\
{[11]} \\
{[12]} \\
{[12]} \\
{[12]} \\
{[12]} \\
{[12]} \\
{[12]} \\
{[12]} \\
{[12]} \\
{[12]} \\
\mathrm{b}\end{array}$ & $\begin{array}{l}2.6-4.8 \\
2.0-3.4 \\
4.0-6.1 \\
4.8-5.6 \\
6.6-8.2 \\
1.9-7.1^{\mathrm{a}} \\
7.1 \\
8.9-12.0 \\
8.0-12.0 \\
11-14 \\
10-13 \\
7-10 \\
2.3-3.1 \\
3.6-5.2\end{array}$ \\
\hline $\begin{array}{l}\mathrm{C}_{11} \\
\mathrm{C}_{12}\end{array}$ & $\begin{array}{l}\text { Modified insulin } \\
\text { (A1-B1 cross linkage): } \\
\text { Undecoyl } \\
\text { Dodecoyl } \\
\text { m-phenylene dithio- } \\
\text { carbamoyl }\end{array}$ & $\begin{array}{l}{[12]} \\
{[12]} \\
{[8]}\end{array}$ & $\begin{array}{l}0.7-1.3 \\
0.5-0.7\end{array}$ \\
\hline
\end{tabular}

a Range obtained with 3 preparations.

b Schermutzki and Brandenburg, unpublished.

Intermolecular linkages. The potency of a dimer with a m-phenylene-dithiocarbamoyl bridge between the B1 phenylalanines of two molecules is on a molar 
basis about $38 \%$ of that of insulin (cf. Table 6). A trimer with $\mathrm{m}$-phenylene-dithiocarbamoyl bridges between $B 1-B^{\prime} 1$ and $A^{\prime} 1-B^{\prime \prime} 1$ is about $16 \%$ active on fat cells (data not shown).

Binding affinities to fat cell receptor sites. The ability of modified insulins in increasing concentrations to inhibit the binding of ${ }^{125} \mathrm{I}$-insulin at equilibrium was studied in order to estimate their binding affinity. Fig. 3 shows the binding curves for ${ }^{125}$ [-insulin in the presence of either native insulin, A1-monoacetyl insulin or des-Gly ${ }^{A 1}$-insulin. The finding of parallel inhibition curves suggested a simple competitive inhibition. Table 6 shows the inhibition constants for 9 different modified insulins and it appears that the binding affinities in per cent of that of native insulin are in agreement with the relative biological potencies. to liver cell membranes and potencies on isolated fat cells for proinsulin, des-Ala ${ }^{\mathrm{B} 30}$-des-Asn ${ }^{\mathrm{A} 21}$-insulin and des-octapeptide ${ }^{\mathbf{B 2}-30}$-insulin. Recently, Freychet, Brandenburg and Wollmer [39] studied the binding affinities to liver cell membranes of acetylinsulins, B1-B1 m-phenylene-dithiocarbamoyl dimer, A1-B29 cross linked derivatives and A1-B1 cross linked derivatives. The results are in agreement with the binding affinities and/or the biological potencies cited in the present report. All of the materials cited above had binding affinities and potencies which were similar to or lower than that of insulin. However, turkey insulin, which has been reported to be more potent in rat fat cells than bovine insulin [40], also exhibits increased binding affinity to fat cell receptors (Gammeltoft and Gliemann, unpublished observation).

Table 6. The binding affinities of modified insulins to fat cells

\begin{tabular}{|c|c|c|c|c|}
\hline $\begin{array}{l}\text { Modified insulin and control native } \\
\text { insulin from same experiment }\end{array}$ & $\begin{array}{l}\text { Ki in } \\
\text { fidenc }\end{array}$ & $\begin{array}{l}\text { M (with } 95 \% \text { con- } \\
\text { limits) }\end{array}$ & $\begin{array}{l}\text { Binding affinity, \% of insulin } \\
\text { (mean) }\end{array}$ & $\begin{array}{l}\text { Biological potency, } \\
\% \text { of insulin }\end{array}$ \\
\hline $\begin{array}{l}\text { Des Phe }{ }^{\mathrm{B} 1} \\
\text { Insulin control }\end{array}$ & $\begin{array}{l}5.4 \\
3.7\end{array}$ & $\begin{array}{l}(4.2-7.0) \\
(2.2-6.6)\end{array}$ & $70 \%$ & $78-102 \%$ \\
\hline A1-monoacotyl & 13.8 & $(9.8-19.3)$ & $25 \%$ & $35-40 \%$ \\
\hline Insulin control & 3.4 & $(2.5-4.8)$ & & \\
\hline A1,B29-diacetyl & 12.2 & $(3.4-39.4)$ & $23 \%$ & $26-32 \%$ \\
\hline Insulin control & 2.8 & $(1.6-5.3)$ & & \\
\hline $\begin{array}{l}\text { Des Gly } \\
\text { Insulin control }\end{array}$ & 394 & $(181-1032)$ & $0.6 \%$ & $0.4-0.6 \%$ \\
\hline$\left[\mathrm{Leu}^{\mathrm{Al}}\right]$ & 31.9 & $(22.9-43.8)$ & $13 \%$ & $14-18 \%$ \\
\hline Insulin control & 4.1 & $(2.9-6.1)$ & & \\
\hline A1-B29-suberoyl & 137 & $(82.9-211)$ & $2.5 \%$ & $1.9-7.1 \%$ \\
\hline $\begin{array}{l}\text { Insulin control } \\
\text { A1-B29-dodecoyl }\end{array}$ & 3.4 & $(2.1-5.8)$ & & \\
\hline $\begin{array}{l}\text { A1-B29-dodecoyl } \\
\text { Insulin control }\end{array}$ & 25.9 & $(16.7-39.2)$ & $10.9 \%$ & $10-13 \%$ \\
\hline $\begin{array}{l}\text { Insulin control } \\
\mathrm{B} 1-\mathrm{B} 1 \mathrm{PBC} \text { dimer }\end{array}$ & 2.8 & $(1.6-5.3)^{\prime}$ & & \\
\hline $\begin{array}{l}\text { B1-B1 PBC dimer } \\
\text { Insulin control }\end{array}$ & 5.8 & $(4.4-7.7)$ & $42 \%$ & $34-40 \%$ \\
\hline $\begin{array}{l}\text { Insulin control } \\
\text { Despentapeptide } \mathrm{B}^{26-30}\end{array}$ & 2.4 & $(1.9-3.2)$ & & \\
\hline $\begin{array}{l}\text { Despentapeptide } \mathrm{B}^{26-30} \\
\text { Insulin control }\end{array}$ & 24.4 & $(15.7-37.6)$ & $14.2 \%$ & $15-18 \%$ \\
\hline & 3.4 & $(1.7-7.1)$ & & \\
\hline
\end{tabular}

\section{Discussion}

The modified insulins with demonstrable biological activity showed the same maximal activity as insulin (i.e. full intrinsic activity) and their log dose-response curves appeared parallel to that of insulin. Furthermore, additive effects were observed for A1-B29 dodecoyl insulin and native insulin, both present in submaximally stimulating concentrations, and none of the modified insulins which were inactive in a concentration of $10^{-8} \mathrm{M}$ were able to block the effect of insulin in low concentrations. Finally the relative potencies were in agreement with the relative binding affinities. Taken together, these findings suggest that the mechanism through which a modification of the insulin molecule may lead to a decrease in biological activity is that the affinity for the receptors is decreased whereas the complex of modified insulin and receptor exhibits full activity. Agreement between the binding affinity and the potency of pro-insulin and of desoctapeptide insulin on fat cells was previously found in this laboratory [20]. Freychet, Roth and Neville [26] have previously shown agreement between binding affinities
The search for biologically essential parts of the insulin molecule has been hampered by the fact that successive removal of amino acids from the $A$ and $B$ chains is accompanied by marked changes in circular dichroism spectra as a sign of changes in the conformation of the remaining part of the molecule. It is therefore impossible to know from this type of study whether a particular amino acid is directly involved in the interaction with the receptor or whether it is essential for the conformation of the whole molecule. Our knowledge from the present work and from the work of other groups, with respect to effects of removal of amino acids, may be summarized as follows: a. carboxy-terminal end of the $B$ chain: removal of 3 amino acids has little effect [27], removal of 5 amino acids causes a quite marked change in circular dichroism spectrum [12] and leaves about $17 \%$ of the potency on fat cells, whereas removal of 8 amino acids causes a marked change in conformation and a decrease to less than $0.2 \%$ activity. b. carboxy-terminal end of the $A$ chain: removal of one amino acid (Asn) causes a quite marked change in conformation and a decrease in potency to a few per cent $[32,26]$. c. amino-terminal 
end of the B chain: removal of one amino acid has no effect on activity and circular dichroism spectrum; removal of 4 amino acids appears to leave a nearly inactive product [28]; this analogue was not isolated and there is therefore no information on conformation. d. amino-terminal end of the A chain: removal of one amino acid (Gly) causes a marked change in conformation [8] and an almost complete abolition of potency on fat cells.

Substitution of Gly ${ }^{\mathrm{A}}$ with acetyl or succinyl residues caused a decline in potency on fat cells to about $40 \%$ and about $15 \%$, respectively, whereas substitution at B1 or B29 had much less effect. Lys ${ }^{\mathrm{A}-1}$-ArgA0 insulin was only about $20 \%$ potent and the replacement of Gly ${ }^{{ }^{1}}$ with valine or proline caused a drop in potency to about $2 \%$ of that of insulin. It is of interest in this connection that split chain proinsulin with the connecting peptide attached to the $\mathrm{N}$-terminal end of the A chain (A1) is about 7\% (or less) potent, whereas split chain proinsulin with the connecting peptide attached to the carboxyl end of the B chain (B30) is about $40 \%$ potent (Gliemann, Gammeltoft and Steiner, unpublished observation). These results stress the importance of the glycine $\mathrm{A} 1$ residue which is located on the surface of an insulin molecule in crystalline state [37]. Arquilla, Bromer and Mercola [36] studied the reactivity to different pools of antibodies of mono (B1) and di (A1,B1) substituted fluorescein insulin and concluded that only the disubstituted derivative, which also showed a marked decrease in activity in vivo, had undergone marked changes in conformation. The results cited above, therefore, agree fairly well with the conclusion reached by Arquilla, Bromer and Mercola on the basis of studies on insulin substituted with fluorescein, iodinated insulin, des-Ala ${ }^{\mathrm{B} 30}$-des-Asn ${ }^{\mathrm{A} 21}$. insulin and desoctapeptide insulin: Any change in conformation results in a proportionate decrease of biologic activity.

On the other hand, the biological activities on fat cells of A1,B29 diacetyl insulin and A1,B29 suberoyl insulin are markedly different $(30 \%$ versus $3 \%)$ in spite of almost identical circular dichroism spectra [12]. The potency of diaminosuberoyl insulin is also reduced to a few per cent even though this derivative is physically very similar to insulin. This suggests that the cross linking affects a biologically important part without causing major changes in the conformation of the molecule. It has been pointed out that the identity between the circular dichroism spectra of A1,B29 diacetyl insulin and A1, B29 suberoyl insulin suggests that the tertiary structure of insulin in solution is similar to that in crystalline state [12]. It is a reasonable suggestion, therefore, that the region of the Gly ${ }^{\mathrm{A}} \mathrm{l}$ residue is located at the surface of the molecule also in solution and that it might participate in the interaction with the receptors of the target cells. The effect of A1,B29 cross linking may be due to either a spatial fixation or to a shielding of the Gly ${ }^{\mathrm{A}}$-region, marking it unsuitable for interaction with receptors.
It seems puzzling that the A1,B29 suberoyl and azelaoyl insulins appear to be fully active in vivo [12], whereas their potency on fat cells (Table 5), their binding affinity to fat cells (Table 6 ) and their binding affinity to liver cell membranes [40] are reduced to $2-10 \%$ of that of insulin. However, we have observed that suberoyl insulin is degraded more slowly than insulin by concentrated fat cell suspensions (Gliemann and Gammeltoft, unpublished observation). It has also been found recently that the half life in dogs of A1-B29 cross linked derivatives is considerably longer than that of insulin (Jones and Sönksen, personal communication). A slower rate of degradation in vivo may therefore explain the apparent discrepancy between the potency in vitro and in vivo.

Aclenowledgements. The cooperation with the group at Deutsches Wollforschungsinstitut working with chemically modified insulins (Research projects St $\mathrm{N} 213-69$, and St N 213 1-71, Bundesministerium für Forschung und Technologie), in particular with Drs. D. Brandenburg, H. G. Gattner and H. Zahn, is gratefully acknowledged. Dr. E. Arquilla is thanked for the sample of desAla ${ }^{B 30}$-des Asn'A21 insulin. Dr. T. Blundel and Dr. G. Dodson are thanked for valuable suggestions. Drs. K.H. Jørgensen and Ulla D. Larsen, NOVO Research Institute are thanked for the supply of ${ }^{125} \mathrm{I}$-labelled insulin.

This study is supported by grants from the Danish Medical Research Council and Nordic Insulin Foundation.

\section{References}

1. Brandenburg, D., Ooms, H.A.: Des-glycineA1-desphenylalanine ${ }^{\mathrm{B} 1}$-insulin and related insulin derivatives. In: Protein and polypeptide hormones, proceedings of the international symposium Liège, May $19-25,1968$, p. $482-484$ (Ed. Margoulies, M.). International Congress Series 161, Excerpta Medica Foundation, Amsterdam

2. Brandenburg, D.: Des-Phe ${ }^{\mathrm{B} 1}$-insulin, ein kristallines Analogen des Rinderinsulins. Hoppe-Seyler's Z. physiol. Chom. 350, 741 - 750 (1969)

3. Weinert, M., Brandenburg, D., Zahn, H.: Peptidsynthesen mit der Insulin-A-Kette. Hoppe-Seylers Z physiol. Chem. 350, 1556-1562 (1969)

4. Brandenburg, D., Biela, M., Herbertz, L., Zahn, H.: Chemical modifications at the amino groups of insulin chains and their influence on biological activity of the hormone. Diabetologia 6, 38 (1970)

5. Weinert, M., Kircher, K., Brandenburg, D., Zahn, H. :

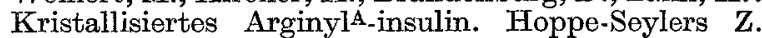
physiol. Chem. 352, 719-724 (1971)

6. Krail, G., Brandenburg, D., Zahn, H., Geiger, R.: [B1-p-Jodphenylalanin] Insulin, ein einheitliches Monojodinsulin. Hoppe-Seylers Z. physiol. Chem. 352, $1595-1598(1971)$

7. Brandenburg, D., Gattner, H.-G., Herbertz, L., Krail, G., Weinert, M., Zahn, H.: Semisynthetic insulin analogues. Biochem. J. 125, 51-52P (1971)

8. Brandenburg, D., Gattner, H.-G., Weinert, M., Herbertz, L., Zahn, H., Wollmer, A.: Structure-function studies with derivatives and analogs of insulin and its chains. In: Diabetes, proceedings of the 7 th Congress of the International Diabetes Federation, Buenos Aires, August 23-28, 1970 (Publ. 1971), p. 363-376. (Eds.: Rodriquez, R.R., Vallance-Owen, J.). International Congress Series 231, Exerpta Medica Foundation, Amsterdam 
9. Zahn, H., Brandenburg, D., Gattner, H.-G.: Molecular basis of insulin action: Contribution of chemical modifications and synthetic approaches. Diabetes 21 (suppl. 2), 468-475 (1972)

10. Brandenburg, D., Gattner, H.-G., Wollmer, A.: Darstellung und Eigenschaften von Acetylderivaten des Rinderinsulins, I. Hoppe-Seylers Z. physiol. Chem. 353, 599-617 (1972)

11. Brandenburg, D.: Proparation of $\mathrm{N}^{\alpha_{\mathrm{A} 1}}, \mathrm{~N}^{\varepsilon_{\mathrm{B} 29}}$-adipoyl insulin, an intramolecularly crosslinked derivative of beef insulin. Hoppe-Seylers Z. physiol. Chem. 353, $869-873$ (1972)

12. Brandenburg, D., Busse, W.-D., Gattner, H.-G., Zahn, H., Wollmer, A., Gliemann, J., Puls, W.: Structure-function studies with chemically modified insulins. In: Proceedings of the 12 th European Peptide Symposium, Reinhardsbrunn Castle, German Democratic Republic, Sept. 24-30, 1972 (Publ. 1973), p. 270-283. (Eds.: Hanson, H., Jakubke, H.-D.). Amsterdam: North-Holland

13. Krail, G.: Semisynthetische N-terminal modifizierte insuline. Thesis. Aachen: Technische Hochschule 1973

14. Berndt, H.: Zur Synthese der Sequenz 60-84 Ala ${ }^{71}$, $\mathrm{Gly}^{72}, \mathrm{Val}^{73}$ des Sehweineproinsulins als monomeres cyclisches Bis-Cystinpeptidderivat Thesis. Aachen: Technische Hochschule 1973

15. Blundell, T., Dodson, G., Hodgkin, D., Mercola, D.: Insulin: The structure in the crystal and its reflection in chemistry and biology. Advanc. Protein Chem. 26, $279-402(1972)$

16. Cuatrecasas, P.: Properties of the insulin receptor of isolated fat cell membranes. J. biol. Chem. 246, $7265-7274(1971)$

17. Kono, T., Barham, F.W.: The relationship between the insulin-binding capacity of fat cells and the cellular response to insulin. J. biol. Chem. 246, 6210-6216 (1971)

18. Freychet, P., Roth, J., Neville Jr., D.M.: Monoiodoinsulin: Demonstration of its biological activity and binding to fat cells and liver membranes. Biochem. biophys. Res. Commun. 43, 400-408 (1971)

19. House, P.D. R. : Kinetics of ${ }^{125}$ I-insulin binding to rat liver plasma membranes. FEBS letters 16, 339-342 (1971)

20. Gammeltoft, S., Gliemann, J.: Binding and degradation of ${ }^{125}$ I-insulin by isolated rat fat cells. Biochim. biophys. Acta 320, 16-32 (1973)

21. Gliemann, J.: Assay of insulin-like activity by the isolated fat cell method I. Factors influencing the response to crystalline insulin. Diabetologia 3, 382-388 (1967)

22. Moody, A.J., Stan, M.A., Stan, M., Gliemann, J.: A simple free fat cell bioassay for insulin-like activity. Hormone Metab. Res.

23. Gliemann, J., Østerlind, K., Vinten, J., Gammeltoft, S.: A procedure for measurement of distribution spaces in isolated fat cells. Biochim. biophys. Acta 286, $1-9$ (1972)

24. Carpenter, F.H.: Relationship of structure to biological activity of insulin as revealed by degradative studies. Amer. J. Med. 40, 750-759 (1966)

25. Bromer, W.W., Chance, R. E.: Preparation and characterization of desoctapeptide insulin. Biochim. biophys. Acta 133, 219-244 (1967)

26. Freychet, P., Roth, J., Neville, Jr., D.M.: Insulin re- ceptors in the liver: Specific binding of ${ }^{125} \mathrm{I}$ insulin to the plasma membrane and its relation to insulin bioactivity. Proc. nat. Acad. Sci. (Wash.) 68, 1833-1837 (1971)

27. Katsoyannis, P. G., Zalut, C., Harris, A., Meyer, R. J. : Analogs of insulin. I. Synthesis of destripeptide $\mathrm{B}^{28-30}$ bovine insulin and destripeptide $\mathrm{B}^{28-30}$ porcine (human) insulin. Biochemistry (Wash.) 10, 3884-3889 (1971)

28. Weitzel, G., Eisele, K., Zellner, H., Weber, V.: Struktur und Wirkung von Insulin VII. Verkürzte synthetische B-Ketten. Hoppe-Seylers Z. physiol. Chem. 350, $1480-1483(1969)$

29. Weber, V., Schneider, F., Köhler, P., Weitzel, G.: Struktur und Wirkung von Insulin I. Synthetische A. Ketten mit variierter Sequenz. Hoppe-Seylers Z physiol. Chem 348, 947-949 (1967)

30. Weber, V., Hörnle, S., Griesen, G., Herzog, K.-H., Weitzel, G.: Struktur und Wirkung von Insulin II. Synthetische A-Ketten mit variierter Sequenz. Hoppe-Seylers Z. physiol. Chem. 348, 1715-1717 (1967)

31. Weber, V., Hörnle, S., Köhler, P., Nagelschneider, G., Eisele, K., Weitzel, G.: Struktur und Wirkung von Insulin III. Synthetische A-Ketten mit variierter Sequenz. Hoppe-Seylers Z. physiol. Chem. 349, 512$514(1968)$

32. Slobin, L.T., Carpenter, F.H.: Action of carboxypeptidase-A on bovine insulin: Preparation of desalanine. desasparagine-insulin. Biochemistry (Wash.) 2, 16$22(1963)$

33. Gliemann, J., Sørensen, H.H.: Assay of insulin-like activity by the isolated fat cell method. IV. The biological activity of proinsulin. Diabetologia $6,499-504$ (1970)

34. Lindsay, D.G., Shall, S.: The acetylation of insulin. Biochem. J. 121, 737-745 (1971)

35. Massaglia, A., Pennisi, F., Rosa, U., Ronca-Testoni, S., Rossi, C.A.: The effect of chemical modifications induced in insulin on the reactivity of the interchain disulphide bonds towards sodium sulphide. Biochem. J. 108, 247-255 (1968)

36. Arquilla, E. R., Bromer, W.W., Mercola, D.: Immuno$\operatorname{logy}$, conformation and biological activity of insulin. Diabetes 18, 193-205 (1.969)

37. Blundell, T.L., Dodson, G.G., Dodson, E., Hodgkin, D.C., Vijayan, M.: X-ray analysis and the structure of insulin. Recent Progr. Hormone Res. 27, 1-34 (1971)

38. Lindsay, D.G.: Intramolecular cross-linked insulin. Febs-letters 21, 105-108 (1972)

39. Freychet, P., Brandenburg, D., Wollmer, A. : Receptorbinding assay of chemically modified insulins. Comparison with in vitro and in vivo bioassays. Diabetologia 10, $1-5(1974)$

40. Weitzel, G., Renner, R., Kemmler, W., Rajer, K.: Struktur und erhöhte Aktivität des Insulins vom Truthuhn (Meleagris gallopavo). Hoppe-Seylers Z. physiol. Chem. 353, 980-986 (1972)

Dr. J. Gliemann

Institute of Medical Physiology C

University of Copenhagen

71, Rådmansgade

DK-2200 Copenhagen N.

Denmark 